\title{
Evidence of bovine leukemia virus circulating in sheep and buffaloes in Colombia: insights into multispecies infection
}

\author{
Nury N. Olaya-Galán ${ }^{1,2}$ • $\cdot$ Adriana P. Corredor-Figueroa ${ }^{3} \cdot$ Sebastián Velandia-Álvarez $^{1}$. \\ Diana S. Vargas-Bermudez ${ }^{4} \cdot$ Nathalia Fonseca-Ahumada $^{1} \cdot$ Kerlimber Nuñez $^{1} \cdot$ Jairo Jaime $^{4}$. \\ María Fernanda Gutiérrez ${ }^{1}$
}

Received: 21 June 2021 / Accepted: 15 September 2021 / Published online: 11 November 2021

(c) The Author(s), under exclusive licence to Springer-Verlag GmbH Austria, part of Springer Nature 2021, corrected publication 2022

\begin{abstract}
Bovine leukemia virus (BLV) is the causative agent of leukemia/lymphoma in cattle. However, previous evidence has shown its presence in other species of livestock as well as in humans, suggesting that other species can be accidental hosts of the virus. In viral infections, receptors that are common to different animal species are proposed to be involved in cross-species infections. For BLV, AP3D1 has been proposed to be its receptor, and this protein is conserved in most mammalian species. In Colombia, BLV has been reported in cattle with high prevalence rates, but there has been no evidence of BLV infections in other animal species. In this study, we tested for the virus in sheep $(n=44)$ and buffaloes $(n=61)$ from different regions of Colombia by nested PCR, using peripheral blood samples collected from the animals. BLV was found in $25.7 \%$ of the animals tested (12 buffaloes and 15 sheep), and the results were confirmed by Sanger sequencing. In addition, to gain more information about the capacity of the virus to infect these species, the predicted interactions of AP3D1 of sheep and buffaloes with the BLV-gp51 protein were analyzed in silico. Conserved amino acids in the binding domains of the proteins were identified. The detection of BLV in sheep and buffaloes suggests circulation of the virus in multiple species, which could be involved in dissemination of the virus in mixed livestock production settings. Due to the presence of the virus in multiple species and the high prevalence rates observed, integrated prevention and control strategies in the livestock industry should be considered to decrease the spread of BLV.
\end{abstract}

\section{Introduction}

Handling Editor: William G Dundon.

Nury N. Olaya-Galán and Adriana P. Corredor-Figueroa have contributed equally as first authors.

María Fernanda Gutiérrez mfgutier@javeriana.edu.co

Nury N. Olaya-Galán

nury.olaya@urosario.edu.co

Adriana P. Corredor-Figueroa

acorredorf@ecci.edu.co

Sebastián Velandia-Álvarez

velandia.s@javeriana.edu.co

Diana S. Vargas-Bermudez dsvargasb@unal.edu.co

Nathalia Fonseca-Ahumada

luisafonseca@javeriana.edu.co

Kerlimber Nuñez

nunez_k@javeriana.edu.co
The livestock industry is one of the most important areas of economic activity in Latin America and is a major source of food and income for the communities [1]. Due to its location,

Jairo Jaime

jjaimec@unal.edu.co

1 Grupo de Enfermedades Infecciosas, Laboratorio de Virología, Departamento de Microbiología, Pontificia Universidad Javeriana, Bogotá, Colombia

$2 \mathrm{PhD}$ Program in Biomedical and Biological Sciences, Universidad del Rosario, Bogotá, Colombia

3 Universidad ECCI, Calle. 51 \# 19-36, Bogotá DC, Colombia

4 Departamento de Salud Animal, Centro de Investigación en Infectología E Inmunología Veterinaria (CI3V), Facultad de Medicina Veterinaria Y de Zootecnia, Universidad Nacional de Colombia, Sede Bogotá, Carrera 30 No. 45-03, 1100 Bogotá, Colombia 
proximity to the equator, climate, and broad landscapes, Latin America has become in one of the largest producers of livestock worldwide [1, 2]. Mixed crop/livestock systems are common in Latin America, with multiple animal species raised together on the same farms [3, 4]. Although some studies have demonstrated the advantages of multi-species farming systems [5-8], these systems require increased labor and management on the farms. As the demand for livestock increases, new challenges also should be considered, such as the management of mixed-species animal herds in terms of food supplies for the animals, water sources, spatial distribution, and control of infectious disease outbreaks [9]. Higher risks of infectious disease transmission might exist due to interactions between different species, favoring the spread and expansion of the host range of microorganisms among animal species and even humans, leading to emerging infectious diseases $[8,10]$.

One of the most important concerns about these infections in multiple animal species is that some animals could remain asymptomatic, serving as intermediate hosts and playing a crucial role in the dissemination of pathogens. Outbreaks of infectious diseases among animals result in economic losses due to the need for treatment, reduction in productivity, early culling of infected animals, and restrictions to their commercial use [10]. Recent outbreaks in mixed livestock production facilities have been reported for both viruses and bacteria, indicating the occurrence of interspecies infections, coinfections with multiple pathogens, and dissemination of multi-drug-resistant bacteria [11, 12]. Crossing the species barrier also increases the risk of spillover to humans [13], as pathogens develop new features, with high mutation rates and recombination processes leading to the emergence of infections with zoonotic potential $[8,10]$.

Bovine leukemia virus (BLV) is a retrovirus with oncogenic potential and is the etiological agent of enzootic bovine leukosis, which is distributed worldwide with high prevalence rates, particularly in Latin America [14]. BLV establishes a persistent infection for the entire life of the animal, but more than $70 \%$ of infected animals remain asymptomatic. The other $30 \%$ develop persistent lymphocytosis, and between 5 and $10 \%$ develop leukemia/lymphoma, which is the most advanced stage of the disease [15]. BLV infection leads to economic losses in the livestock industry, as it increases the risk of secondary infections in the host, decreases milk production, favors weight loss, and increases the risk of abortions and other unfavorable clinical outcomes $[16,17]$.

BLV appears to be a versatile infectious agent, as evidence of natural infections has been reported in multiple animal species [18, 19], including buffaloes [20], yaks [21, 22], sheep [23, 24], and alpacas [25]. In addition, BLV has been found in breast tissue [26, 27], lungs [28], and blood [29] of humans, suggesting the occurrence of zoonotic infections, which might be associated with cancer development [30-32]. Recently, co-circulation of the virus among humans and cattle was also reported, with evidence of transfer of molecular signatures and genetic flux between species [33]. This suggests that food products obtained from infected cattle could be a potential source of viral dissemination and zoonosis [34]. One of the proposed mechanisms of cross-species infection is the use of receptors that are conserved among species, allowing viruses to replicate in both natural and accidental hosts [35]. For BLV, transport proteins such as AP3D1 (adaptor-related protein complex-3) [36, 37] and CAT1/SLC7A1 (cationic amino acid transporter-1/solute carrier family 7 member 1) [38] have been identified as potential receptors in cattle. These proteins interact with the gp51 Env protein, which is located in the viral envelope and mediates viral entry into the host cells [39]. In our research group, interactions between bovine AP3D1 and the gp51 Env protein of BLV have been characterized using both in silico and in vitro techniques [36]; however, there is no evidence of interactions with the corresponding proteins of other animal species, despite the presence of the virus in other animal hosts.

In Colombia, BLV was detected recently with high prevalence rates $(62 \%)$ in the cattle industry, distributed throughout the main livestock production regions in the country [40]. The livestock industry in Colombia, and in Latin America in general, has a strong impact on its economic development, with a significant expansion in the last decade [2]. Mixed livestock farms are common in Colombia, particularly those with cattle, sheep, and buffaloes, which are species that have undergone a significant increase in their populations. Both sheep and buffaloes are raised commercially as sources of meat for human consumption and for production of milk and dairy products [41, 42]. Although Colombia has an epidemiological surveillance system for animal health administered by ICA (Instituto Colombiano Agropecuario), there are still gaps in the diagnosis and control of infectious diseases listed in the OIE Terrestrial Animals Health Code [43]. Enzootic bovine leukosis is considered a disease of concern by the OIE [44], but unfortunately, is not included in the official standards of control of animal diseases in Colombia, and thus, diagnosis is not supported by the government $[45,46]$. Considering the high prevalence of BLV in Colombian cattle [40] and evidence of the virus in other livestock species in other regions, this study was aimed at determining whether the virus is circulating in sheep and buffaloes in Colombia, as no studies are available that focused on these species. Likewise, as part of the supporting evidence of the natural infection of these species, in silico modeling of the AP3D1 proteins of buffaloes and sheep and their interactions with the gp51 protein of BLV was performed. 


\section{Materials and methods}

\section{Analysis of AP3D1 of multiple species and interactions with gp51 of BLV}

\section{Retrieval and multiple alignment of AP3D1 sequences}

To investigate the plausibility of natural transmission of BLV to other species present on mixed farms, as well as its zoonotic potential, sheep, goat, buffalo, deer, alpaca, pig, horse, and human AP3D1 sequences were retrieved from the National Center for Biotechnology Information (NCBI, USA) database and compared to the bovine AP3D1 sequence as a reference (Table 1). Multiple sequence alignment (MSA) was performed using the ClustalW tool available in MEGA7 software [47]. The final alignment was visualized and edited using Jalview Ver2.11.1.4 [48].

\section{AP3D1 and Env protein 3D structures and docking simulations}

Protein structures used in this study were predicted previously by our research group [36]. Briefly, COPI (PDB ID $5 \mathrm{~A} 1 \mathrm{U}$ ) and AP2 adaptor complex (PDB ID 2VGL) crystal structures were used as templates for modeling the $3 \mathrm{D}$ structures of Env and bovine AP3D1, respectively. To avoid the need to build a new model for the AP3D1 protein of each species, the mutation wizard function in PyMOL [49] was used to mutate the amino acids that were different in the BLV receptor (BLVR) domain of AP3D1 of buffalo and sheep based on the MSA described above, using the bovine AP3D1 model as a template.

Each of the AP3D1 structural models was then used for molecular docking to the gp51 region of Env protein of BLV, using HADDOCK software [50]. For the docking

Table 1 Accession numbers for AP-3 complex subunit delta-1 (AP3D1) protein sequences of cattle, humans, and ungulate species

\begin{tabular}{ll}
\hline Accession number & Species \\
\hline NP_003929.4 & Homo sapiens \\
NP_776423.3 & Bos taurus \\
XP_005682664.1 & Capra hircus \\
XP_006206482.1 & Vicugna pacos \\
XP_020761624.1 & Odocoileus virginianus \\
XP_020939857.1 & Sus scrofa \\
XP_023500114.1 & Equus caballus \\
XP_024849589.1 & Bos taurus \\
XP_025148895.1 & Bubalus bubalis \\
XP_027402912.1 & Bos indicus \\
XP_027825737.1 & Ovis aries \\
\hline
\end{tabular}

protocol, residues in Env gp51 and boAP3D1 that were identified previously as being relevant for binding between the two proteins were included in the model: 97A, 98S, $115 \mathrm{H}$, $127 \mathrm{~W}, 128 \mathrm{E}$, and $170 \mathrm{~N}$ for gp51 and 695D, 800R, 807D, and $925 \mathrm{~K}$ for AP3D1 [36]. Residues surrounding the active region were selected as passive in the model, and all of them could interact indirectly. HADDOCK scores for the interactions were also obtained.

\section{Screening of BLV circulating in sheep and buffaloes in Colombia}

\section{Population and sample collection}

As no previous evidence of BLV in buffaloes and sheep in Colombia was available, a convenience sampling strategy was used for virus detection in these species. Figure 1 shows the regions where mixed production facilities are present. Currently, there are about 28 million bovines, 1.7 million sheep, and 500,000 buffaloes in these regions [51], with a BLV prevalence of $62 \%$ in cattle [40]. Blood samples were taken from 61 buffaloes and 44 sheep from different departments of the country. Buffalo samples were collected on farms in Antioquia $(n=40)$ and Cundinamarca $(n=21)$, and sheep samples were obtained from slaughterhouses located in Cundinamarca $(n=22)$ and Santander $(n=22)$ (Fig. 1). On average, the buffaloes were about 2-3 years of age, and the sheep were 5-6 months old.

Whole blood samples were collected in Vacutainer tubes with EDTA and were shipped to the virology lab at the Pontificia Universidad Javeriana (Bogota) for processing. Mononuclear cells were separated by density gradient centrifugation using LymphoSep separation medium (MP) following the manufacturer's instructions. Total DNA was extracted using a High Pure PCR Template Preparation Kit (Roche) as instructed by the manufacturer. Total DNA was stored at $-20^{\circ} \mathrm{C}$ until later use.

\section{Detection of BLV proviral DNA and phylogenetic analysis}

The integrity and quality of the extracted DNA was verified by the amplification of constitutive genes for both species by conventional PCR. bovGAPDH ( $856 \mathrm{bp}$ ) and cytochrome $\mathrm{C}$ (267 bp) housekeeping genes were used for buffaloes and sheep, respectively. Samples that were negative for housekeeping gene amplification were excluded from the study.

BLV detection was carried out by nested PCR targeting a region of the Tax gene of the virus (284 bp). Primers and PCR conditions used in this study were reported previously [26]. Tests were carried out using PCR master mix (Sigma-Aldrich) following the instructions of the manufacturer, with a final volume of $25 \mu \mathrm{L}$ and a primer 


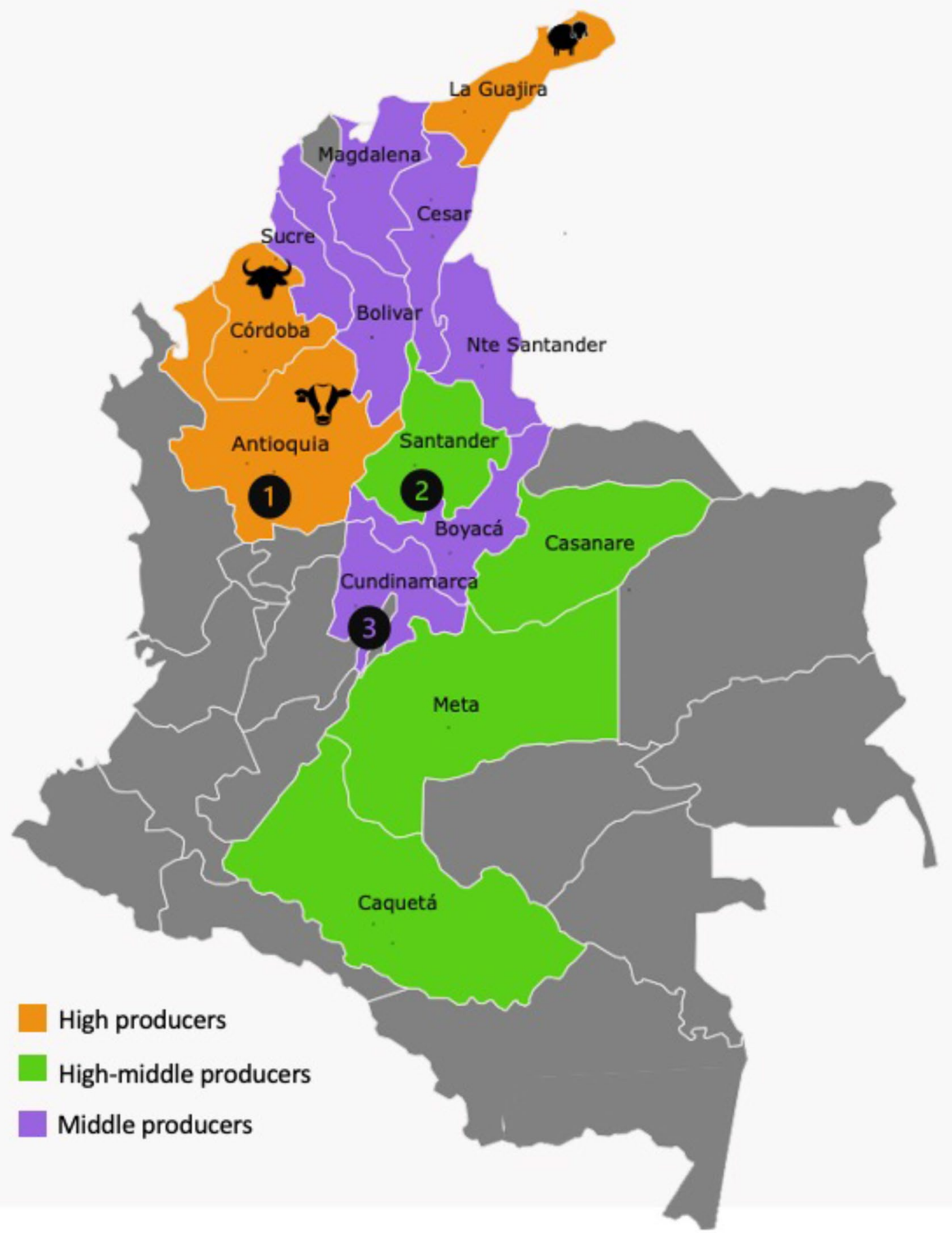

Fig. 1 Regions with mixed-species livestock production in Colombia. Antioquia, Cordoba, and La Guajira are the departments with the highest production of cattle $(n=3,000,000)$, buffaloes $(n=90,000)$, and sheep $(n=800,000)$. Colors indicate the population density of animals of multiple species, divided into high producers ( $>2$ million animals), high-middle producers (1-2 million animals), and middle producers $(300,000-1$ million animals) [51]. *Regions in gray rep- resent small or non-producers with fewer than 300,000 animals in the department. Numbers indicate the locations where samples were collected. Buffalo samples were collected in Antioquia (1) and Cundinamarca (3), and sheep samples were collected in Santander (2) and Cundinamarca (3). The map was created with Pixel Map Generator, available online (https://pixelmap.amcharts.com) 
concentration of $0.8 \mathrm{pmol} / \mu \mathrm{L}$. Amplicons were analyzed by electrophoresis in $1.5 \%$ agarose gels in TAE buffer, stained with Diamond Nucleic Acid Dye (Promega). DNA obtained from a fetal lamb kidney (FLK) cell line persistently infected with BLV was used as a positive control. DNase/RNase-free, molecular-grade water was used as a negative control.

PCR products from buffalo and sheep samples with the highest DNA concentrations were purified and shipped to the SIGMOL sequencing service of Universidad Nacional, Colombia, for Sanger sequencing. An inner 115-bp region of the amplified PCR product was used for sequencing, using the primer set $F$ (TGTCACCATCGATGCCTG G)/R (CATCGGCGGTCCAGTTGATA). The identity of the sequences was verified using BLASTn. Sequences obtained from buffaloes $(n=4)$ and sheep $(n=3)$ were compared with 97 complete BLV genome sequences retrieved from the GenBank database. Information about the sequences and FASTA files are available in the supplementary materials of this article. Sequences were aligned by the ClustalW method in MEGA7 [47]. The best evolutionary model was selected automatically using the "Find Model" option integrated in MEGA software, which is based on the Akaike information criterion (AIC) [52]. Phylogenetic reconstruction was also performed in MEGA7 by the maximum-likelihood method, with 1000 bootstrap pseudoreplicates. FigTree program Ver1.4.4 was used to visualize and edit the phylogenetic tree (http://tree. bio.ed.ac.uk/software/figtree/).

\section{Results}

\section{AP3D1 sequence alignment and molecular docking simulations}

AP3D1 sequences retrieved from the GenBank database were filtered for the proposed BLVR domain in cattle (aa 660-807) [36]. A multiple alignment was performed to identify regions that are conserved among species. Figure 2 shows an alignment of AP3D1 amino acid sequences using boAP3D1 as a reference. The residues predicted to interact with BLV-gp51 are colored in red, and these were found to be conserved in all of the species compared. Sequence variations were found only in regions that were not predicted to interact with BLV-gp51. All of the sequences were at least $95 \%$ identical to that of bovine AP3D1.

Since the most common livestock species raised together on farms in Colombia are cattle, sheep, and buffaloes, the AP3D1 proteins of these species were selected for modeling of molecular docking. The BLVR domain of buffalo AP3D1 differed from that of cattle by only two amino acid substitutions, R734Q and V777I, whereas in sheep, the BLVR domain was identical to that of cattle.

Figure 3 shows the results of docking simulations using sheep or buffalo AP3D1 and gp51. In both models, the region interacting with gp51 belongs to the BLVR domain. The HADDOCK score and binding affinity of the complex

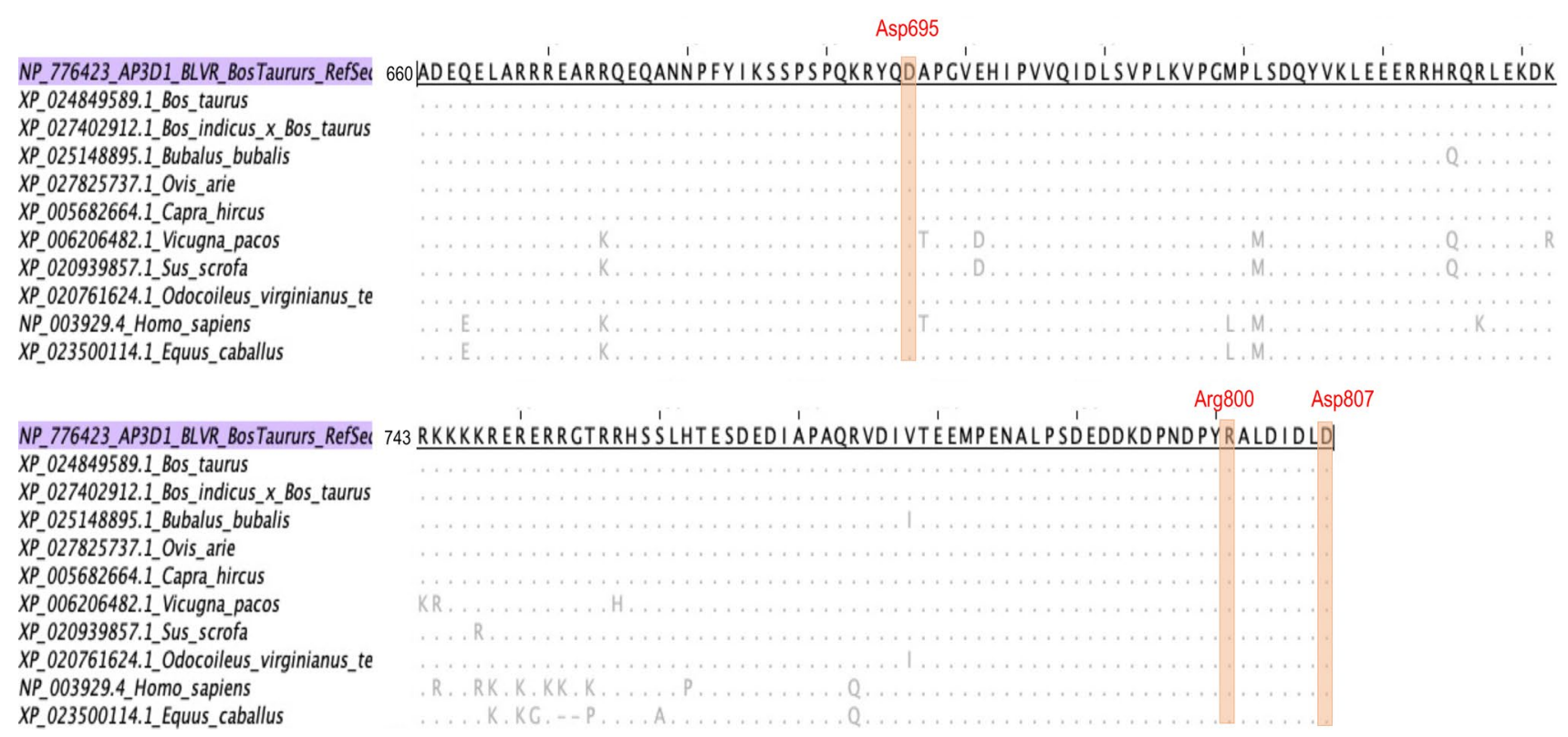

Fig. 2 ClustalW multiple alignment of AP3D1 sequences of mammals, including ungulate animals and humans, using bovine AP3D1 as a reference. The region between aa 660 and aa 807 is shown, which belongs to the BLVR domain in cattle. The residues that inter- act with the BLV gp51 protein are highlighted in red. These amino acids were conserved in all species. Sequence variations were identified outside the range of the residues of interest for the interaction with gp51. 


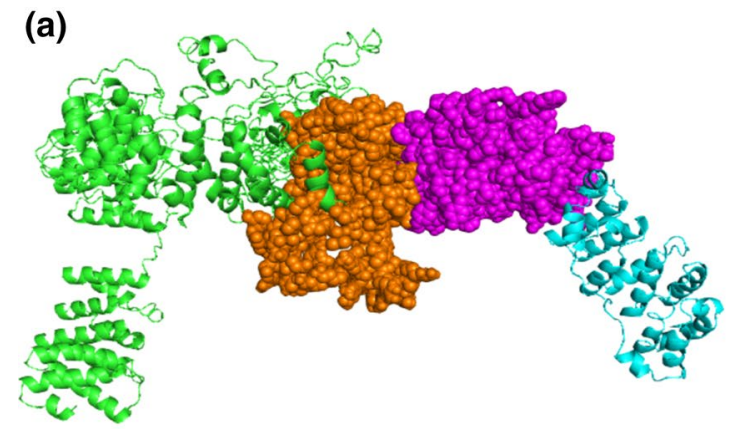

Fig. 3 Molecular docking simulations of AP3D1 and gp51 proteins. The AP3D1 protein is shaded in green for both species. The BLVR domain is highlighted in orange for sheep (a) and in red for buffalo (b). The Env protein is shaded in cyan, and the gp51 domain is high-

Table 2 BLV detection in sheep and buffaloes in different regions of Colombia

\begin{tabular}{|c|c|c|c|c|}
\hline \multirow[t]{2}{*}{ Species } & \multicolumn{3}{|c|}{ BLV detection by department } & \multirow{2}{*}{$\begin{array}{l}\text { BLV total* } \\
\text { n }(\%)\end{array}$} \\
\hline & $\begin{array}{l}\text { Antioquia } \\
\text { n (\%) }\end{array}$ & Cundinamarca & Santander & \\
\hline $\begin{array}{l}\text { Buffaloes }(\mathrm{n}= \\
61)\end{array}$ & $5(8.19)$ & $7(11.4)$ & -- & $12(19.67)$ \\
\hline Sheep $(n=44)$ & -- & $9(20.45)$ & $6(13.63)$ & $15(34.09)$ \\
\hline
\end{tabular}

The results are shown as frequencies and percentages for each region $-n(\%)$

*BLV total represents cumulative frequency and percentage per species

were $-395.7+/ 6.2$ and $-11.9 \mathrm{kcal} / \mathrm{mol}$, respectively, for sheep AP3D1 and $-387.8+/-7.6$ and $-10.5 \mathrm{kcal} / \mathrm{mol}$, respectively, for buffalo AP3D1.

\section{Evidence of BLV in sheep and buffaloes in Colombia}

BLV was detected in both sheep and buffaloes located in the three departments included in the study. Frequencies per species and region are shown in Table 2. BLV was detected in 15 of the 44 sheep samples and in 12 of the 61 buffalo samples, representing a positivity rate of $25.7 \%$ overall for the samples included in the study.

For phylogenetic analysis, positive samples with the highest concentration of the PCR product were selected for sequencing. The resulting sequences (sheep, $\mathrm{n}=3$, buffaloes, $n=4$ ) were analyzed using BLASTn and found to be more than $99 \%$ identical to BLV sequences from Colombian cattle. In the phylogenetic reconstruction (Fig. 4), sequences were evenly distributed among reference sequences and other Colombian sequences obtained from cattle and cattlederived food products. No specific branches were identified for BLV detected in sheep or buffaloes.

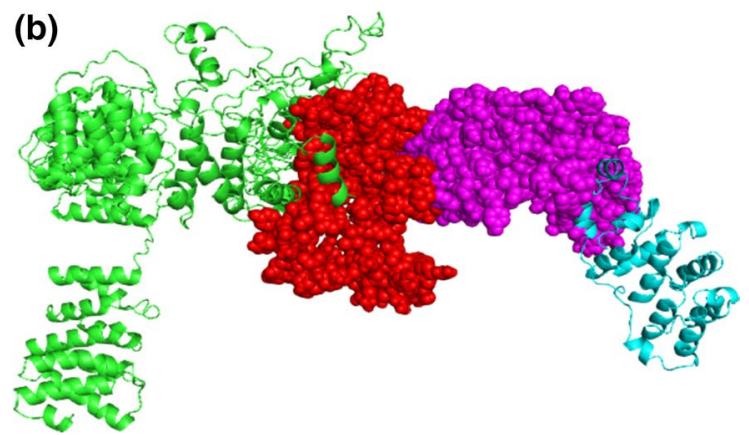

lighted in magenta. For both species, interactions between AP3D1 and the Env protein were predicted to involve the BLVR domain and gp51.

\section{Discussion}

Emerging infectious diseases are a topic of concern from the One Health point of view, which proposes management of infectious diseases as part of a whole system that includes animal, human, and environmental health, due to the interactions between species and the environment, favoring transmission and spread of microorganisms that can adapt to novel hosts or ecological niches [53, 54]. Particularly for potential zoonotic infections, adaptation profiles, spillover events, evolutionary fitness, and susceptibility of new potential hosts to infections should be considered, and strategies are needed for integrated management, prevention, and control of infectious diseases [55]. One of the concerns for microorganisms crossing the species barrier, especially viruses, is the interaction with cellular receptors that are present in multiple animal species, increasing the range of infection in nature [10,35]. In this study, the AP3D1 receptor of BLV was analyzed, a transporter protein that is present in multiple eukaryotic species, including mammals [56]. The results of this study showed a high degree of conservation in this protein among cattle, sheep, and buffaloes (Fig. 2), particularly in the BLVR domain, from aa 660 to 803 . In the docking simulation (Fig. 3), it was found that the AP3D1 protein of sheep and buffaloes was predicted to be able to bind to the gp51 protein of BLV with no differences in the binding domain compared to that predicted for bovine AP3D1 [36], supporting the hypothesis of the natural infection with BLV in these species, as was also supported by the HADDOCK scores and binding affinity predicted in the analysis, which were similar for both species. These interactions between AP3D1 of different species and BLV-gp51 would be expected to allow a broader host range for the virus, and this could explain the presence of BLV in multiple species. Evidence of use of the same receptor for crossspecies infections has also been reported for other viruses, 


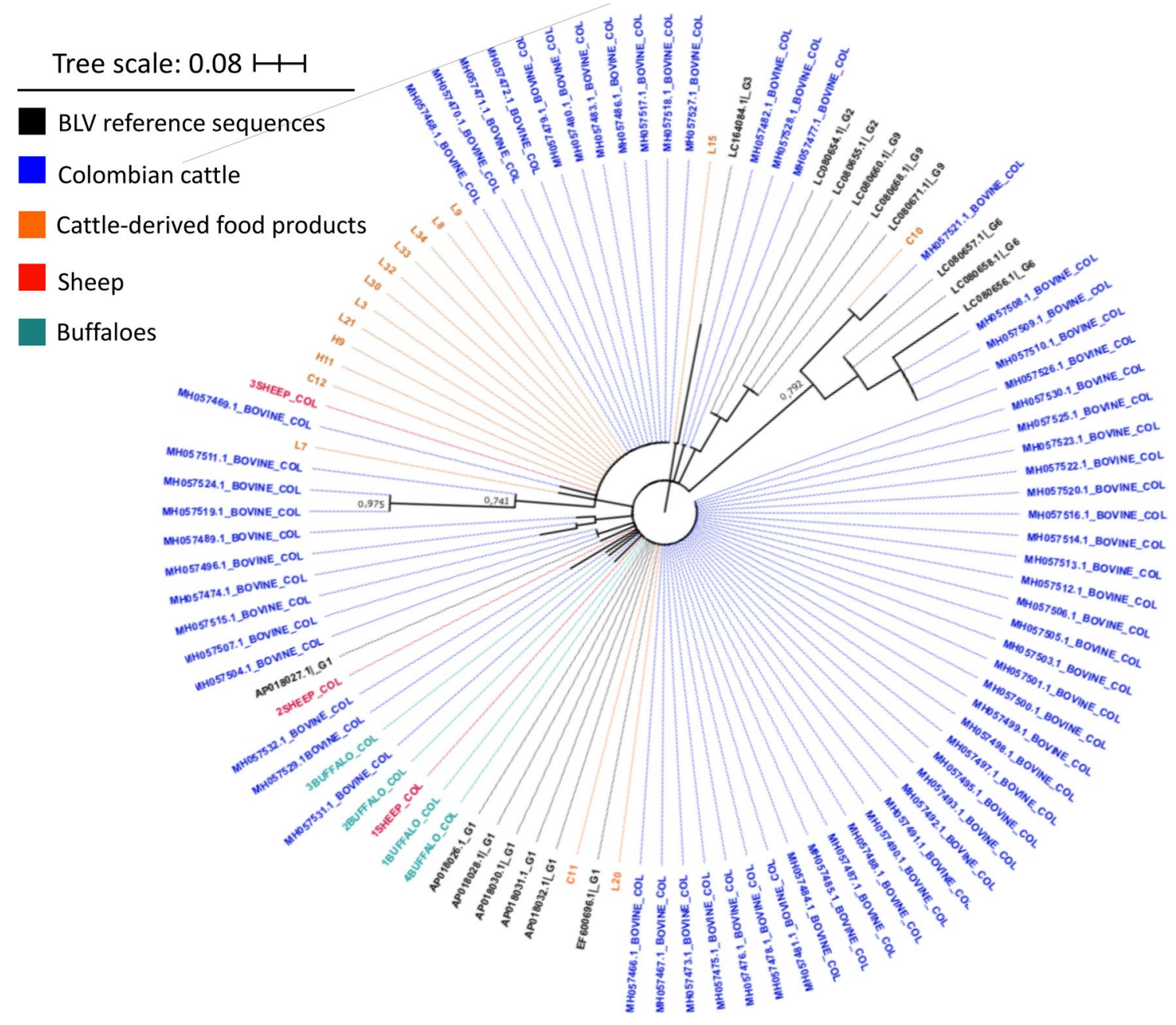

Fig. 4 Unrooted maximum-likelihood phylogenetic tree obtained using a multiple alignment of the complete data set $(n=104$ sequences) produced using ClustalW and the Tamura-Nei model [52]. A region of the $\operatorname{tax}$ gene is shown. A discrete gamma distribution was used to model evolutionary rate differences among sites: 5

including those with zoonotic potential such as influenza virus [57] and the current pandemics SARS-CoV-2 [58].

BLV has classically been studied in cattle regarding its implications for productivity, animal health, and the economic losses it causes for farmers and cattle keepers [17]. Although most infected animals remain asymptomatic, one of the biggest concerns is the spread of the virus among herds, which has been seen in the cattle industry, with high prevalence rates around the world, mainly in major cattleproducing countries [14]. Generally, in Colombia and in Latin America, cattle are slaughtered at an early age, except for females used for milk and reproduction purposes. For meat purposes, cattle are slaughtered between 2 and 3 years of age [41]. Lymphoma/leukemia development tends to occur in older cattle 3 years of age or more $[59,60]$. Although BLV often remains undetected due to the removal categories, $+\mathrm{G}$ parameter $=0.4839$. Colors indicate the source of the BLV sequence as follows: black, BLV reference sequences; blue, cattle (blood); orange, cattle (food products, milk and beef); red, sheep; teal, buffaloes

of asymptomatic infected animals from the herds at an early age, the circulation and persistence of an oncogenic virus among animals has consequences in the long term, affecting animal health and food quality.

The results of this study suggest that BLV infects other species in regions of Colombia where it has been detected in cattle [40]. Few strategies are available for the prevention and control of BLV [61]. As no vaccines are available, prevention and control strategies are limited to managing risk factors associated with the transmission of the virus, such as use of disposable materials (e.g., syringes, needles, gloves), cleaning and disinfection of utensils, and segregating and culling infected animals. These strategies are useful for preventing the spread of infection $[17,62]$ but are not always implemented in the livestock industry. The detection of BLV in multiple species increases the challenge of management 
and control of the viral infection and monitoring its dissemination and transmission patterns. Good veterinary practices should be considered for improving animal health and preventing cross-infections, particularly in mixed-species herds.

One of the biggest concerns in Latin America and the Caribbean is the lack of support by governments for diagnosis, and no budget is available for this purpose. In Europe, eradication programs have been established with successful results in at least 22 countries through rigorous surveillance programs financed by the government [63-66]. Chile is the only country in Latin America in which epidemiological surveillance has been implemented and an eradication program has started [67]. Efforts to establish eradication programs for the elimination of BLV should be made in the livestock industry as a prevention and control strategy whose impact will be seen in the future. Improvements in diagnosis and surveillance programs are necessary as a basis for followup of BLV infections in cattle as well as other intermediate hosts in which the virus could be spreading [68].

In Colombia, sheep and buffaloes are increasing in importance in the livestock industry and are commonly present on mixed-species farms, which have significantly increased in number in the last decade. Now, although the Instituto Colombiano Agropecuario (ICA) [69] exists as a regulatory party within the country and oversees animal health and surveillance programs, follow-ups for these animal species are limited and should be improved in order to gain better and broader coverage in terms of detection and control of infectious diseases. BLV is included in the list of viruses for which reporting is mandatory, which means that farmers/ laboratories that perform voluntary diagnosis and detect the virus within their herds are required to report the presence of the virus to the government [45], but since it is not considered an officially controlled disease, it is not the responsibility of the government to perform diagnosis and verify that herds are BLV-free, as is the case with foot-and-mouth disease, rabies, tuberculosis, and brucellosis [70]. The lack of control of infections in buffaloes, sheep, and cattle facilitates the dissemination of BLV through livestock trading and commercialization.

There have been few reports of the presence of BLV in sheep and buffaloes in other regions, but it is becoming an important topic in the livestock industry worldwide. In Latin America, a previous study in Venezuela showed that BLV was present in buffalo milk on about $27 \%$ of farms tested in Maracaibo $(n=22)$ [71], while in the southeast and Amazon regions of Brazil, BLV was not detected in a study that included 300 buffaloes [72]. In contrast, a study in Egypt found a seroprevalence of $9 \%$ in buffaloes on mixed farms with cattle and camels [20], and in Pakistan, the virus was found in $0.8 \%$ of analyzed samples [73]. Antibodies against BLV were detected in sheep in the state of Sao Paulo in Brazil, although the incidence was very low, with only two out of 2592 sheep sera testing positive [24]. In Iran, the presence of BLV in mixed herds of cattle, sheep, and camels was investigated, and it was found in sheep (5.7\%) and cattle (23\%), but not in camels [23].

Since there was no information available about the presence of the virus in species other than cattle in Colombia, we used a convenience sampling strategy for the screening of the virus in buffaloes and sheep. The frequency of detection ( $11 \%$ in buffaloes and $20 \%$ in sheep) was higher than in other geographical regions. Although it is not known whether similar BLV infection rates will be found in other departments where buffaloes and sheep are located, these results can be used as a basis for further epidemiological studies with broader populations of animals to determine the current prevalence rates of BLV in Colombia, especially on mixed-species farms. Phylogenetic analysis (Fig. 4) performed with the sequences obtained from sheep and buffaloes in the current study and previously reported sequences from Colombian cattle, suggested that the circulating virus could be the same as that obtained from cattle, since no separate branches were identified in the phylogenetic tree for sequences obtained from sheep and buffaloes [40].

The presence of BLV in multiple species, its high prevalence rate (62\%) in cattle in Colombia [40], and the potential for co-circulation of the virus in cattle and humans [33] should raise concerns for regulatory agencies and livestock producers, as BLV infections are unfavorable for the animal production sector $[16,17]$, and the zoonotic potential of the virus has implications for human health [31, 74]. Accumulating evidence in the literature suggesting that BLV can infect multiple species should raise concerns about elevated dissemination rates on mixed-species farms, in wildlife reservoirs, and in accidental hosts, which could hamper prevention and control strategies to stop the spread of the virus. Efforts should be taken towards the development of new strategies for follow-up of the virus and the implementation of eradication programs similar to those used in Europe so that in the future, herds worldwide will become BLV-free as part of the One Health initiative [54].

\section{Conclusions}

We found evidence of BLV circulation in sheep and buffaloes in Colombia, with $25.7 \%$ positivity in the animals tested. Also, the potential interaction of the AP3D1 proteins of these species with the BLV gp51 protein suggest that AP3D1 could be used as a receptor for BLV in buffaloes and sheep, which might play a role in the dissemination of the virus on mixed-species farms, potentially complicating prevention and control strategies and surveillance programs. 
Supplementary Information The online version contains supplementary material available at https://doi.org/10.1007/s00705-021-05285-7.

Acknowledgements The authors would like to acknowledge the participants from the research groups at Pontificia Universidad Javeriana and Universidad Nacional, who supported the experiments, as well as the veterinarians and participating slaughterhouses for sample collection, especially Dr. Edgar Torres and Dr. Eric Schachtebeck for collection of buffalo samples.

Author contributions Conceptualization: APC-F, DSV-B, NNO-G, MFG. Methodology: SV-Á, NF-A, KN, DSV-B. Formal analysis and investigation: APC-F, NNO-G, SV-Á, DSV-B, JJ, MFG. Writingoriginal draft preparation: APC-F, SV-Á, DSV-B. Writing-review and editing: SV-Á, NNO-G, JJ, MFG. Funding acquisition: MFG. Resources: MFG, JJ. Supervision: JJ, MFG.

Funding This work was supported by Ministerio de Ciencia, Tecnología e Innovación de Colombia (MinCiencias) through Fondo de Ciencia Tecnología e Innovación/Sistema General de Regalías, in the national call $009 / 2020$ for research projects as part of the strategy of strengthening regional laboratories with the potential of providing scientific and technological services to address infectious diseases' research areas related to high-risk pathological agents with an impact on human health, supporting research and diagnosis for SARS-CoV-2, and other pathological agents of public health interest. A grant was awarded to Dr. Gutierrez, received through the Pontificia Universidad Javeriana, BPIN project 2020000100127.

\section{Declarations}

Conflict of interest The authors have no relevant financial or non-financial interests to disclose.

Availability of data and materials Sequences used in the current study have been deposited in the GenBank database and are freely accessible. Further information is supplied in the supplementary material.

Ethical approval Results published in this study were obtained within the research project "EVALUACIÓN EPIDEMIOLÓGICA Y MOLECULAR DEL VIRUS DE LA LEUCOSIS BOVINA Y DE LOS VIRUS ASOCIADOS AL COMPLEJO RESPIRATORIO Y REPRODUCTIVO BOVINO, OVINO Y BUFALINO EN COLOMBIA" approved by the ethics committee of Pontificia Universidad Javeriana (Acta No 8/2018 - Comité de investigación y ética de la Facultad de Ciencias) and was also approved by CICUA (Comité Institucional de Cuidado y Uso de Animales) at Pontificia Universidad Javeriana (A-003-18) for animal protection purposes.

\section{References}

1. FAO Regional Office-LATAM (2021) Livestock production in Latin America and the Caribbean I FAO Regional Office for Latin America and the Caribbean I Food and Agriculture Organization of the United Nations. In: FAO. http://www.fao.org/americas/prior ities/produccion-pecuaria/en/. Accessed 1 Jun 2019

2. Williams G, Anderson D (2020) The Latin American livestock industry: growth and challenges. Choices 34:1-11

3. Morales GA Tropical livestock: production and management. In: Tropical biology and conservation management. UNESCO-EOLSS
4. Oosting SJ, Udo HMJ, Viets TC (2014) Development of livestock production in the tropics: farm and farmers' perspectives. Animal 8:1238-1248. https://doi.org/10.1017/S1751731114000548

5. Jerrentrup JS, Komainda M, Seither M et al (2020) Diverse swards and mixed-grazing of cattle and sheep for improved productivity. Front Sustain Food Syst 3:1-14. https://doi.org/10.3389/fsufs. 2019.00125

6. Kitsteiner J (2014) Multispecies Grazing: An Introduction I Temperate Climate Permaculture. https://tcpermaculture.com/site/ 2014/08/26/multispecies-grazing-an-introduction/. Accessed 10 Jun 2019

7. Fraser MD, Rosa García R (2018) Mixed-species grazing management to improve sustainability and biodiversity. Rev Sci Tech 37:247-257. https://doi.org/10.20506/rst.37.1.2755

8. Martin G, Barth K, Benoit M et al (2020) Potential of multi-species livestock farming to improve the sustainability of livestock farms: a review. Agric Syst. https://doi.org/10.1016/j.agsy.2020. 102821

9. OECD/FAO (2019) OECD-FAO Agricultural Outlook 2019-2028. Rome

10. Brooks DR, Hoberg EP, Boeger WA, Trivellone V (2021) Emerging infectious disease: an underappreciated area of strategic concern for food security. Transbound Emerg Dis. https://doi.org/10. 1111/tbed.14009

11. Shabana II, Krimly RA (2020) Seroprevalence of some viral and bacterial zoonoses in domestic ruminants in Medina. J Adv Vet Anim Res 7:42-50. https://doi.org/10.5455/JAVAR.2020.G391

12. Gebreyes WA, Jackwood D, de Oliveira CJB et al (2020) Molecular epidemiology of infectious zoonotic and livestock diseases*. Microbiol Spectr 8:1-21. https://doi.org/10.1128/microbiolspec. ame-0011-2019

13. Sánchez CA, Venkatachalam-Vaz J, Drake JM (2021) Spillover of zoonotic pathogens: a review of reviews. Zoonoses Public Health. https://doi.org/10.1111/zph.12846

14. Polat M, Takeshima S, Aida Y (2017) Epidemiology and genetic diversity of bovine leukemia virus. Virol J 14:209. https://doi.org/ 10.1186/s12985-017-0876-4

15. Barez P-Y, de Brogniez A, Carpentier A et al (2015) Recent advances in BLV research. Viruses 7:6080-6088. https://doi.org/ 10.3390/v7112929

16. Bartlett PC, Ruggiero VJ, Hutchinson HC et al (2020) Current developments in the epidemiology and control of enzootic bovine leukosis as caused by bovine leukemia virus. Pathogens 9:1-13

17. Juliarena MA, Barrios CN, Lützelschwab CM et al (2017) Bovine leukemia virus: current perspectives. Virus Adapt Treat 9:13-26

18. Mammerickx M, Portetelle D, Burny A (1981) Experimental cross-transmissions of bovine leukemia virus (BLV) between several animal species. Zentralblatt für Veterinärmedizin R B 28:69-81. https://doi.org/10.1111/j.1439-0450.1981.tb01740.x

19. Feliziani F, Martucciello A, Iscaro C et al (2017) Bovine leukemia virus: experimental infection in buffaloes and evaluation of diagnostic test reliability. Res Vet Sci 114:450-454. https://doi. org/10.1016/j.rvsc.2017.07.021

20. Selim A, Marawan MA, Ali A-FF et al (2020) Seroprevalence of bovine leukemia virus in cattle, buffalo, and camel in Egypt. Trop Anim Health Prod 52:1207-1210. https://doi.org/10.1007/ s11250-019-02105-8

21. Ma JG, Bin ZW, Zhou DH et al (2016) First report of bovine leukemia virus infection in yaks (Bos mutus) in China. Biomed Res Int. https://doi.org/10.1155/2016/9170167

22. Wang M, Wang Y, Baloch AR et al (2017) Molecular epidemiology and characterization of bovine leukemia virus in domestic yaks (Bos grunniens) on the Qinghai-Tibet Plateau, China. Arch Virol 163:659-670. https://doi.org/10.1007/s00705-017-3658-9

23. Nekoei S, Hafshejani TT, Doosti A, Khamesipour F (2015) Molecular detection of Bovine leukemia virus in peripheral blood 
of Iranian cattle, camel and sheep. Pol J Vet Sci 18:703-707. https://doi.org/10.1515/pjvs-2015-0091

24. del Fava C, de Donato TM, MIF B et al (2010) Occurrence of seropositive sheep (Ovis aries) to Bovine Leukemia Virus in Brazil. Braz J Vet Res Anim Sci 47:483-487. https://doi.org/10.11606/ issn.1678-4456.bjvras.2010.26811

25. Lee LC, Scarratt WK, Buehring GC, Saunders GK (2012) Bovine leukemia virus infection in a juvenile alpaca with multicentric lymphoma. Can Vet J La Rev vétérinaire Can 53:283-286

26. Buehring GC, Shen HM, Jensen HM et al (2014) Bovine leukemia virus DNA in human breast tissue. Emerg Infect Dis 20:772-782. https://doi.org/10.3201/eid2005.131298

27. Mesa G, Ulloa JC, Uribe AM et al (2013) bovine leukemia virus gene segment detected in human breast tissue. Open J Med Microbiol 3:84-90. https://doi.org/10.4236/ojmm.2013.31013

28. Robinson LA, Jaing CJ, Pierce Campbell C et al (2016) Molecular evidence of viral DNA in non-small cell lung cancer and nonneoplastic lung. Br J Cancer 115:497-504. https://doi.org/10. 1038/bjc.2016.213

29. Buehring GC, DeLaney A, Shen $\mathrm{H}$ et al (2019) Bovine leukemia virus discovered in human blood. BMC Infect Dis 19:297. https:// doi.org/10.1186/s12879-019-3891-9

30. Buehring GC, Sans HM (2020) Breast cancer gone viral? Review of possible role of bovine leukemia virus in breast cancer, and related opportunities for cancer prevention. Int J Environ Res Public Health. https://doi.org/10.3390/ijerph17010209

31. Cuesta LM, Lendez PA, Victoria M et al (2018) Can bovine leukemia virus be related to human breast cancer? A review of the evidence. J Mammary Gland Biol Neoplasia. https://doi.org/10. 1007/s10911-018-9397-z

32. Kim Y, Pierce CM, Robinson LA (2018) Impact of viral presence in tumor on gene expression in non-small cell lung cancer. BMC Cancer 18:843. https://doi.org/10.1186/s12885-018-4748-0

33. Corredor-Figueroa AP, Olaya-Galán NN, Velandia S et al (2021) Co-circulation of bovine leukemia virus haplotypes among humans, animals, and food products: new insights of its zoonotic potential. Int J Environ Res Public Health. https://doi.org/10.3390/ ijerph18094883

34. Olaya-Galán NN, Corredor-Figueroa AP, Guzmán-Garzón TC et al (2017) Bovine leukaemia virus DNA in fresh milk and raw beef for human consumption. Epidemiol Infect 145:3125-3130. https://doi.org/10.1017/S0950268817002229

35. Parrish CR, Holmes EC, Morens DM et al (2008) Cross-species virus transmission and the emergence of new epidemic diseases. Microbiol Mol Biol Rev 72:457-470. https://doi.org/10.1128/ mmbr.00004-08

36. Corredor AP, Gonzales J, Baquero LA et al (2018) In silico and in vitro analysis of boAP3d1 protein interaction with bovine leukaemia virus gp51. PLoS ONE 13:1-18. https://doi.org/10.1371/ journal.pone.0199397

37. Suzuki T, Matsubara Y, Kitani H, Ikeda H (2003) Evaluation of the delta subunit of bovine adaptor protein complex 3 as a receptor for bovine leukaemia virus. J Gen Virol 84:1309-1316. https:// doi.org/10.1099/vir.0.18763-0

38. Bai L, Sato H, Kubo Y et al (2019) CAT1/SLC7A1 acts as a cellular receptor for bovine leukemia virus infection. FASEB J. https://doi.org/10.1096/fj.201901528R

39. Lairmore MD (2014) Animal models of bovine leukemia virus and human T-lymphotrophic virus type-1: insights in transmission and pathogenesis. Annu Rev Anim Biosci 2:189-208. https://doi. org/10.1146/annurev-animal-022513-114117

40. Corredor-Figueroa AP, Salas S, Olaya-Galán NN et al (2020) Prevalence and molecular epidemiology of bovine leukemia virus in Colombian cattle. Infect Genet Evol 80:104171. https://doi.org/ 10.1016/j.meegid.2020.104171
41. Garnica-Gomez LF (2018) CADENAS CÁRNICAS BOVINABUFALINA: Dirección de cadenas pecuarias, pesqueras y acuícolas, Bogotá

42. Hidalgo P (2020) CADENA OVINO-CAPRINA: Dirección de cadenas pecuarias, pesqueras y acuícolas, Bogotá

43. OIE (2021) Terrestrial Animal Health Code 2021, Paris

44. OIE (2019) Enzootic Bovine Leukosis. In: OIE Terrestrial Manual. OIE

45. Instituto Colombiano Agropecuario (2015) Resolucion 3714- "Por la cual se establecen las enfermedades de declaración obligatoria en Colombia", Bogotá

46. Díaz O, Mendoza E, Linares C et al (2019) Sanidad Animal (2016). Subgerencia de Protección Animal. Instituto Colombiano Agropecuario, Bogota

47. Kumar S, Stecher G, Tamura K, Dudley J (2016) MEGA7: molecular evolutionary genetics analysis version 7.0 for bigger datasets. Mol Biol Evol 33:1870-1874. https://doi.org/10.1093/molbev/ msw054

48. Waterhouse AM, Procter JB, Martin DMA et al (2009) Jalview Version 2-a multiple sequence alignment editor and analysis workbench. Bioinformatics 25:1189-1191. https://doi.org/10. 1093/bioinformatics/btp033

49. Schrödinger L (2015) The PyMOL Molecular Graphics System, Version 2.0

50. de Vries SJ, van Dijk ADJ, Krzeminski M et al (2007) HADDOCK versus HADDOCK: new features and performance of HADDOCK2.0 on the CAPRI targets. Proteins 69:726-733. https://doi.org/10.1002/prot.21723

51. Instituto Colombiano Agropecuario (ICA) (2021) Censo Pecuario Nacional - año 2021, Bogotá

52. Tamura K, Nei M (1993) Estimation of the number of nucleotide substitutions in the control region of mitochondrial DNA in humans and chimpanzees. Mol Biol Evol 10:512-526. https://doi. org/10.1093/oxfordjournals.molbev.a040023

53. Degeling C, Johnson J, Kerridge I et al (2015) Implementing a One Health approach to emerging infectious disease: reflections on the socio-political, ethical and legal dimensions. BMC Public Health 15:1-11

54. Ellwanger JH, da Veiga ABG, de Kaminski VL et al (2021) Control and prevention of infectious diseases from a One Health perspective. Genet Mol Biol 44:e20200256. https://doi.org/10.1590/ 1678-4685-GMB-2020-0256

55. Plowright RK, Parrish CR, McCallum H et al (2017) Pathways to zoonotic spillover. Nat Rev Microbiol 15:502-510. https://doi. org/10.1038/nrmicro.2017.45

56. Odorizzi G, Cowles CR, Emr SD (1998) The AP-3 complex: a coat of many colours. Trends Cell Biol 8:282-288

57. Romero-Tejeda A, Capua I (2013) Virus-specific factors associated with zoonotic and pandemic potential. Influenza Other Respi Viruses 7:4-14. https://doi.org/10.1111/irv.12075

58. Damas J, Hughes GM, Keough KC et al (2020) Broad host range of SARS-CoV-2 predicted by comparative and structural analysis of ACE2 in vertebrates. Proc Natl Acad Sci USA 117:2231122322. https://doi.org/10.1073/pnas.2010146117

59. Tajima S, Ikawa Y, Aida Y (1998) Complete bovine leukemia virus (BLV) provirus is conserved in BLV-infected cattle throughout the course of B-cell lymphosarcoma development. J Virol 72:7569-7576

60. Yoon SS, Bae YC, Lee KH et al (2005) Characteristics of bovine lymphoma caused by bovine leukemia virus infection in HolsteinFriesian dairy cattle in Korea. Asian-Australasian J Anim Sci 18:728-733. https://doi.org/10.5713/ajas.2005.728

61. Abdala A, Alvarez I, Brossel H et al (2019) BLV: lessons on vaccine development. Retrovirology 16:1-6. https://doi.org/10.1186/ s12977-019-0488-8 
62. Ortiz-Ortega D, Sanchez A, Tobón J et al (2016) Seroprevalence and risk factors associated with bovine leukemia virus in Colombia. J Vet Med Anim Heal 8:35-43. https://doi.org/10.5897/ JVMAH2016.0457

63. Acaite J, Tamosiunas V, Lukauskas K et al (2007) The eradication experience of enzootic bovine leukosis from Lithuania. Prev Vet Med 82:83-89. https://doi.org/10.1016/j.prevetmed.2007.05.010

64. Hayes D (1998) Enzootic bovine leucosis eradication scheme. Surveillance 25:8-11

65. Nuotio L, Rusanen H, Sihvonen L, Neuvonen E (2003) Eradication of enzootic bovine leukosis from Finland. Prev Vet Med 59:43-49. https://doi.org/10.1016/S0167-5877(03)00057-6

66. Maresca C, Costarelli S, Dettori A et al (2015) Enzootic bovine leukosis: report of eradication and surveillance measures in Italy over an 8-year period (2005-2012). Prev Vet Med 119:222-226. https://doi.org/10.1016/j.prevetmed.2015.02.024

67. MinAgricultura-Chile (2010) CERTIFICACIÓN OFICIAL DE PREDIOS LIBRES Y UNIDADES COLECTIVAS LIBRES DE BRUCELOSIS Y/O TUBERCULOSIS Y/O LEUCOSIS BOVINA, Santiago

68. Bartlett PC, Sordillo LM, Byrem TM et al (2014) Options for the control of bovine leukemia virus in dairy cattle. J Am Vet Med Assoc 244:914-922. https://doi.org/10.2460/javma.244.8.914

69. Instituto Colombiano Agropecuario (2021) Protección Animal I ICA. In: ICA - MinAgricultura. https://www.ica.gov.co/areas/ pecuaria?lang=es-co. Accessed 19 Jun 2019
70. Díaz O, Mendoza E, Linares C et al (2019) SANIDAD ANIMAL 2016 - ICA, Bogota-

71. Rosales-zambrano D, Paiva-Ramirez RP-R, Quiñonez-Rojas F (2016) Determination of antibodies against Bovine Leukaemia Virus, Brucella sp. and Bovine Viral Diarrhea Virus using the bulk milk Elisa in buffaloes farms in the region south lake Maracaibo, Venezuela. Rev CES Med Vet y Zootec 11:216. https://doi. org/10.13140/RG.2.2.13072.40964

72. De Oliveira CHSS, Resende CF, Oliveira CMCC et al (2016) Absence of Bovine leukemia virus (BLV) infection in buffaloes from Amazon and southeast region in Brazil. Prev Vet Med 129:9-12. https://doi.org/10.1016/j.prevetmed.2016.05.002

73. Meas S, Seto J, Sugimoto C et al (2000) Infection of bovine immunodeficiency virus and bovine leukemia virus in water buffalo and cattle populations in Pakistan. J Vet Med Sci 62:329-331. https:// doi.org/10.1292/jvms.62.329

74. Gyles C (2016) Should we be more concerned about bovine leukemia virus? Can Vet J = La Rev Vet Can 57:115-116. https:// doi.org/10.1371/journal.pone.0134304

Publisher's Note Springer Nature remains neutral with regard to jurisdictional claims in published maps and institutional affiliations. 